\title{
Using of hurdles technology to improve the quality characteristics of chicken fillets during storage
}

\author{
M.I. Ibrahium ${ }^{1,}{ }^{*}$, A.I. Hegazy ${ }^{1}$, A.S. Osheba ${ }^{2}$ and A.M. Nageib ${ }^{1}$ \\ ${ }^{1}$ Food Science and Technology Department, Faculty of Agriculture, AL-Azhar University, Cairo, Egypt \\ ${ }^{2}$ Food Technology Research Institute, Agricultural Research Center, Giza, Egypt \\ * Correspondence: Mohammedibrahim700.el@azhar.edu.eg (M. I. Ibrahim) \\ ABSTRACT
}

\begin{abstract}
Food is the major source of energy in our lives as it performs various activities. This study was carried out to evaluate the effect of some hurdle technology methods and different packaging on the properties of physicochemical, microbiological and sensorial for treated chicken fillet samples during the storage periods and to compare them with control samples (without treatment). The samples were soaked in solution contains: glycerol $5 \%$, sodium chloride $6 \%$, propylene glycol $1 \%$, lactic acid $1 \%$ and sorbic acid $0.2 \%$ for 2 hours and semi-fried using a traditional fryer at $180 \pm 5^{\circ} \mathrm{C}$ for $4 \mathrm{~min}$ before packaged. The samples were packaged by two methods aerobically packaged and vacuum packaged and then stored under three conditions: Storage at room temperature $\left(25 \pm 5{ }^{\circ} \mathrm{C}\right)$, storage at cold temperature $\left(4 \pm 2{ }^{\circ} \mathrm{C}\right)$ and storage at frozen temperature $\left(-18 \pm 2{ }^{\circ} \mathrm{C}\right)$. The results showed that using of some hurdle technology methods retarded the development of rancidity and impeded the growth of microorganisms in chicken fillet samples at different storage conditions compared to the control samples. In conclusion, the vacuum packaging showed the best protection towards reducing the values of TVBN, TBA, $\mathrm{pH}$ and frying loss, as well as maintaining good sensory quality properties in tested samples during storage periods compared to aerobic packaging.
\end{abstract}

Keywords: Hurdles technology; Chicken fillet; Storage; Oxidative stability; Microorganisms.

\section{INTRODUCTION}

Food plays a key role in our life, as it is the major source of energy to perform various activities. According to mode of action, the food preservation techniques can be categorized into three: (A) Slowing down or inhibiting the chemical deterioration and microbial growth. (B) Directly involving the bacteria, yeasts, molds and enzymes. (C) Avoiding recontamination of food following and before processing. Most of the current preservation techniques employed for preservation of foods is related to any of these three above mentioned criteria. Great efforts have been done towards preventing the use of a single preservation technique for food preservation to meet the requirement of consumer. However, when it comes to food safety and shelf life, one has to look for some more complex procedure for preserving the foods, (Gould, 1995 and Pal, et al. 2014). When the preservation fails, the consequences range from minor deterioration, such as colour loss, to food becoming extremely hazardous (Gould, 1995). In recent years, the demand for fresh and good quality food products has led to the emergence of hurdle technology.

The main objective of hurdle technology is food preservation (Leistner, 2000), storage of food products (Pal, et al. 2014) and enhancement of their shelf life thereby giving us good quality products (Pundir and Murtaza, 2015; Singh and Shalini, 2016).

Some of the hurdles such as temperature (high or low), water activity (aw), preservatives (nitrite and sorbate), competitive microorganisms (lactic acid bacteria) and acidity $(\mathrm{pH})$ have been empirically used for years to stabilize meat, fish, milk and vegetables (Leistner, 2000). The basic concept is to apply combinations of existing and novel preservation techniques ("hurdles") in order to eliminate the growth of micro-organisms. Therefore, the aim of effective food preservation is to control all forms of quality deterioration, the overriding priority is always to minimize the potential for the occurrence and growth of food spoilage and food poisoning microorganisms (Gayán et al., 2012).

Many interrelated factors can influence the shelf life of poultry meat such as environmental conditions (temperature, humidity, light and oxygen), water content, indigenous enzymes and most importantly, microorganisms. Consequently, developing and combining preservation methods to extend shelf life and increase safety of these products is of great importance. Thus, traditional preservation techniques such as vacuum packaging and modified atmosphere packaging can be combined with decontaminants, additives (natural or chemical), natural bio-preservatives and/or be integrated to emerging technologies 
such as active and intelligent packaging (Totosaus and Kuri, 2007).

Poultry meat is a very popular food commodity around the world and its consumption has increased over the last decades in many countries. Some of the reasons for the popularity are the relatively low cost of production, low fat content and the high nutritional value of poultry meat. Considering the fact that poultry belongs to perishable foods, the main concern of industries is the shelf-life extension of the poultry products. Modern trends to achieve this goal include the application of the hurdle technology concept (Leistner, 1995).

Fillet (fresh or frozen) is more widely used in the food industry in comparison with other parts of chicken, whereas it is more susceptible to spoiling. Hence, food industry focuses on finding modern methods and technologies to increase the shelf life of fillet (Petrou et al., 2012).

Therefore, the present study has been carried out to evaluate the effect of some hurdle technology methods and different packaging on the properties of physicochemical, microbiological and sensorial for treated chicken filet samples during the storage periods and compare them with control samples (without treatment).

\section{Materials and Methods}

Chicken breast meat: Deboned skinned fresh chicken breast meat (breast fillet) was purchased from the local market, Nasr City, Cairo, Egypt and transported to the laboratory within $30 \mathrm{~min}$. It was held at refrigerator at $4^{\circ} \mathrm{C}$ until using.

\section{Other ingredients:}

Other ingredients: condiments (Fresh onion and garlic, 1:1), wheat flour $72 \%$, spices mix, fresh whole eggs, sunflower oil, leavening agent, commercial baking powder, fresh onion, parsley, dill, bread crust, skimmed milk and salt were obtained from the local market, Nasr City, Cairo, Egypt

\section{Chemicals:}

The chemicals needed for the study were obtained from Sigma Chemical Company and El-Nasr Pharmaceutical Chemicals, Cairo Egypt.

Polyethylene pouches: Food grade pouches were used in aerobic packaging, and lowdensity polyethylene (LDPE) bags pouches used for vacuum packaging were purchased from Makhlouf Sons Company, El-Mosky, Cairo Egypt.

\section{Experimental Treatments:}

\section{Preparation of Chicken Fillet:}

Chicken meat fillet prepared as follows: deboned chicken breast meat was cut manually into middle pieces. The chicken fillet samples were formed into characteristic shapes $(10 \times 2 \times 5$ $\mathrm{cm})$, each weighing $90-100 \mathrm{~g}$. The chicken meat fillets were soaked in solution contains: glycerol $5 \%$, sodium chloride $6 \%$, propylene glycol $1 \%$, lactic acid $1 \%$ and sorbic acid $0.2 \%$ for 2 hours, then frozen at $-18{ }^{\circ} \mathrm{C}$ according to the method described by Jafari et al. (2017). The frozen control and treated chicken fillet samples were pre-dusted with refined wheat flour and dipped in batter (The batter formulations were composed of solid and water in a ratio of 3:5). The solid content of the batter formulations contained equal amounts of corn and wheat flour. In addition, $1.0 \%$ salt and $0.5 \%$ leavening agent and commercial baking powder were added to the formulation for $15 \mathrm{~s}$ and then drained for $5 \mathrm{~s}$. Next, the battered fillet was placed on a layer of bread crumbs for $5 \mathrm{~s}$ for each side. Finally, the battered and breaded fillet were placed on a sheet of aluminium foil waiting to be deep-fat semi fried (Dogan et al., 2005). The breaded chicken fillet were semifried using a traditional fryer at $180 \pm 5{ }^{\circ} \mathrm{C}$ for 4 min then they were drained in a frying basket from excess oil for $30 \mathrm{~s}$ and placed on paper towel for $1 \mathrm{~min}$ to absorb excess oil then it were cooled at room temperature on aluminium foil sheet for $20 \mathrm{~min}$ before packaging (RoseteHidalgo et al., 2008).

\section{Packaging of chicken fillet samples:}

The samples were packaged by two methods aerobically packaged and vacuum packaged then storage under three conditions: Storage at room temperature $\left(25 \pm 5 \mathrm{C}^{\circ}\right)$, storage at cold temperature $\left(4 \pm 2 \mathrm{C}^{\circ}\right)$ and storage at frozen temperature $\left(-18 \pm 2 C^{\circ}\right)$.

For vacuum packaging: The samples were packaged according to the method described by Bolumar et al. (2011) in polyethylene film and low density polyethylene (LDPE) bags pouches by using 2 stage vacuum pump (model 2FY-3P, Herisau, Schwiez).

For aerobic packaging: The samples were loosely packaged in film polyethylene pouches: Food grade pouches were used in aerobic packaging. 


\section{Cooking of Chicken fillet:}

For sensory evaluation and determination of cooking measurements, control and treated chicken fillet samples were fried by traditional fryer at $180{ }^{\circ} \mathrm{C}$ for 4 min either at zero time or after each storage period then they were drained in a frying basket from excess oil for 30 $\mathrm{s}$ and placed on paper towel for $1 \mathrm{~min}$ to absorb excess oil then it were cooled at room temperature on aluminium foil sheet for $20 \mathrm{~min}$ (Rosete-Hidalgo et al., 2008).

\section{Analytical Methods:}

The control and treated chicken fillet samples were periodically analysed every 3 days during storage at room temperature, every 15 days during storage at cold temperature and every 30 days during storage at frozen temperature. Data obtained after analysis were statistically analyzed.

Determination of Physicochemical properties for chicken fillet:

\section{Total volatile bases nitrogen:}

Total volatile bases nitrogen (TVBN) in the tested chicken fillet samples was determined according to the method described by Mwansyemela (1973).

\section{Thiobarbituric acid:}

The thiobarbituric acid (TBA) in the tested chicken fillet samples was determined by the distillation method outlined by Tarladgis et al. (1960).

\section{pH Value:}

$10 \mathrm{~g}$ of minced chicken fillet sample were blended with $90 \mathrm{ml}$ distilled water and measured with a standard combined electrode attached to a digital $\mathrm{pH}$ meter (Jenway, $3510 \mathrm{pH}$ meter, UK) according to the method described by Vareltzis et al. (1997).

\section{Frying loss (\%):}

Frying loss (\%) of prepared chicken fillet samples was calculated according to the method described in A.M.S.A. (1995), as follows:

$\%$ frying loss $=$ Fresh sample weight - cooking sample weight $\times 100$ / Fresh sample weight

\section{Determination of color:}

Surface color of chicken fillet samples was measured instrumentally by a Hunter lab digital colorimeter (TCPIIG system, Beijing Optical Instrument Co. Ltd., China) using CIE color parameters $\mathrm{L}^{*}$ (light/dark) $\mathrm{a}^{*}$ (red/green) and $b^{*}$ (yellow/blue) values. The $L^{*} a^{*} b^{*}$, or CIE
Lab, color space is an international standard for color measurements, adopted by the Commission Internationaled Eclairage (CIE) in 1976 (Mery et al., 2006). Color measurements were taken from four different positions.

The instrument was calibrated with black and white standard plates before the analysis. Each data point was the mean of four replications. The following calculations were done to determine the attribute of $\Delta \mathrm{E}$ indicates the degree of overall color change (Viana et al. 2005).

Where $\Delta \mathrm{E}$ indicates the degree of overall color change in comparison to color values of an ideal control chicken fillet. $L^{*}$ sample, a*sample and $b^{*}$ sample measure direct from sample and $\mathrm{L}^{*}$ standard, $\mathrm{a}^{*}$ standard and $\mathrm{b}^{*}$ standard for standard of instrument. $\left(\Delta \mathrm{L}^{*_{2}}+\Delta \mathrm{a}^{*_{2}}+\Delta \mathrm{b}^{*_{2}}\right)$ it is a square difference between the measured

$$
\begin{aligned}
& \Delta L^{*}=L_{\text {sample }}^{*}-L_{\text {standard }}^{*} ; \Delta a^{*}=a_{\text {sample }}^{*}-a_{\text {standard }}^{*} ; \\
& \Delta b^{*}=b_{\text {sample }}^{*}-b_{\text {standard }}^{*} . \\
& \Delta E=\sqrt{\left(\Delta L^{* 2}+\Delta a^{* 2}+\Delta b^{* 2}\right)} .
\end{aligned}
$$

value and the standard value.

\section{Microbiological Analysis of Chicken fillet:}

The microbiological examinations of chicken fillet samples included determination counts of total bacterial, coliform group, psychrophilic bacteria, mold and yeast, anaerobic bacteria, staphylococcus aurous and clostridium were determined according to A.P.H.A. (1976) and Difco Manual (1984). While, salmonella spp. was determined according to FAO (1979).

\section{Sensory Evaluation of Cooked Chicken fillet:}

Sensory quality attributes of treated chicken fillet samples were evaluated at zero time and during different storage periods, and compare them with control samples (without treatment). Cooked samples were left to cool at room temperature for $15 \mathrm{~min}$. before being subjected to organoleptic evaluation as described by Twig et al. (1976). The samples were evaluated by thirty panelists from staff members and graduate students of Food Science and Technology Department, Faculty of Agriculture, Al Azhar University. Cairo, Egypt. The panelists were asked to evaluate color, odor, taste, tenderness, juiciness, and overall acceptability. During the panel test, rinse the panellist's mouth by water to remove any traces of residual food. The scores ranging from $0-10$ $(0-3=$ very poor, $4=$ poor, $5=$ fair, $6-7=\operatorname{good}$ and $8-10=$ very good). 


\section{Statistical Analysis:}

Data were subjected to Analysis of Variance (ANOVA). The Least Significant Difference (LSD) procedure was used to test for difference between means (significance was defined at $\mathrm{p}<0.05)$ as reported by Snedecor and Cochran (1994).

\section{RESULTS AND DISCUSSION}

Effect of some hurdle technology methods on physicochemical quality criteria for chicken fillets during storage:

\section{Total volatile bases nitrogen (TVBN) content:}

Total volatile bases nitrogen (TVBN) could be used as an indication of decomposition which occurs by bacteria and protein breakdown during storage (Moawad, 1995). Total volatile bases nitrogen is a mixture of many volatile nitrogenous compounds, such as ammonia and other lower simple mono amines (El-Akel 1988).

The results from Table (1) showed that TVBN values of chicken fillet samples treated by aerobic packaging or vacuum packaging were lower $(\mathrm{P}<0.05)$ than control sample at initial storage. The control sample recorded 2.84 mg N2/100g sample, while the samples treated by aerobic packaging recorded TVBN values from 2.41 to $2.57 \mathrm{mg} / 100 \mathrm{~g}$ and the samples treated by vacuum packaging recorded values from 2.21 to $2.54 \mathrm{mg} / 100 \mathrm{~g}$ under the same conditions.

Also, no significant differences were observed between chicken fillet samples treated by aerobic packaging and vacuum packaging under initial storage at room temperature, but significantly differed $(\mathrm{P}<0.05)$ at cold storage and frozen storage.

Also from Table (1), it could be observed that TVBN values of all samples were gradually increased $(\mathrm{P}<0.05)$ during storage periods with different packaging methods. The different control samples showed the highest values of TVBN at the end of each storage period compared with treated samples. Where, TVBN content of stored control sample at room temperature increased from 2.84 to 19.56 $\mathrm{mg} / 100 \mathrm{~g}$ after 3 days and chicken fillet sample treated by aerobic packaging increased from 2.57 to $21.15 \mathrm{mg} / 100 \mathrm{~g}$ after 12 days, while treated sample by vacuum packaging increased from 2.54 to $19.81 \mathrm{mg} / 100 \mathrm{~g}$ after 18 days. The tested hurdle technology methods and vacuum packaging of chicken fillet samples significantly reduced the formation of total volatile nitrogen as compared to aerobic packaging (Ntzimani et al., 2010).

Also, the other chicken fillet samples stored at cold and frozen temperatures were encountered the same trend. TVBN content in treated samples by aerobic packaging and vacuum packaging reached to 22.18 and 19.42 $\mathrm{mg} / 100 \mathrm{~g}$, respectively, after 75 and 135 days of cold storage, and 19.95 and $21.10 \mathrm{mg} / 100 \mathrm{~g}$ after 120 and 180 days of frozen storage as shown in Table (1).

This increase could be mainly attributed to the effect of microorganisms as well as autolysis processes (Hashem et al., 1978). Generally, these results are in agreement with those obtained by Kacaniova et al. (2019).

Moreover, after 18 day of storage at room temperature and 150 day of frozen storage, the samples treated by vacuum packaging were in the range of permissible level of TVBN as reported by E.O.S. (2005), which recommends that TVBN content in frozen samples not exceed $20 \mathrm{mg} \mathrm{N} / 100 \mathrm{~g}$ sample. Also, chicken fillet sample treated by vacuum packaging and stored at cold temperature was within safe limits until the end of storage period (19.42 $\mathrm{mg} / 100 \mathrm{~g})$. While, control and samples treated by aerobic packaging at these previous periods were spoiled as shown in Table (1).

Noteworthy that the samples treated by aerobic packaging and stored at room and cold temperature were exceeded the maximum permissible limits at 12 and $75^{\text {th }}$ storage, respectively.

\section{Effect of some hurdle technology methods on thiobarbituric acid (TBA) content for chicken fillets during storage:}

Thiobarbituric acid (TBA) test is used as an index for measuring oxidative rancidity (malonaldehyde formation) which takes place in meat and meat products. TBA test is a sensitive test for the decomposition products of highly unsaturated fatty acids which do not appear in peroxide value determination (Younathan et al., 1980 and Melton, 1983).

TBA values of both different control samples and treated samples as affected by tested hurdle technology methods and different packaging with extended storage periods on room temperature, cold temperature and frozen temperature for different periods are presented in Table (2).

From the results of Table 2 it could be noticed that significant $(P<0.05)$ differences were recorded in TBA values among the tested 
samples at initial storage. The control sample recorded $0.183 \mathrm{mg}$ malonaldehyde/ $\mathrm{kg}$ sample, while samples treated by aerobic packaging recorded values from 0.160 to $0.189 \mathrm{mg} / \mathrm{kg}$, and the samples treated by vacuum packaging were ranged $0.165-0.198 \mathrm{mg} / \mathrm{kg}$. These results are in line with those obtained by Alahakoon et al., (2014).

Also, at initial storage under the room and cold temperatures, TBA contents of samples treated by vacuum packaging were higher (0.198 and $0.187 \mathrm{mg} / \mathrm{Kg}$, respectively) than samples treated by aerobic packaging $(0.189$ and $0.160 \mathrm{mg} / \mathrm{Kg})$ and control sample $(0.183$ $\mathrm{mg} / \mathrm{Kg}$ ), while the sample treated by vacuum packaging was lower $(0.165 \mathrm{mg} / \mathrm{Kg})$ than sample treated by vacuum packaging $(0.178$ $\mathrm{mg} / \mathrm{Kg}$ ) at frozen temperature.

Also, Table (2) indicated that TBA contents of all tested samples gradually increased $(\mathrm{P}<$ 0.05 ) during storage periods up to the end. The different control samples showed the highest contents of TBA at the end of each storage period compared with treated samples. The tested hurdle technology methods and vacuum packaging reduced lipid oxidation for chicken fillet samples during storage, since TBA values of aerobic packaged samples were higher than that of vacuum packaged ones. This increase could be mainly attributed to the oxidation of chicken fillets lipids and formation of some TBA-reactive compounds during the storage period as reported by Alahakoon et al. (2014). While, Davies and Board (1998) reported that the increase in TBA content during frozen storage could be attributed to the psychrophillic bacteria producing lipases causing lipolytic activities of fat as well as increase the level of free fatty acid. It is worth mentioning that the increment rates in TBA contents were decreased with treatment of chicken fillet samples by vacuum packaging. Generally, these results are in agreement with those obtained by Hassanzadeha et al. (2017), who mentioned that TBA content of meat and chicken samples increased with increasing of the storage period.

Moreover, after 15 day storage at room temperature and 150 day of frozen storage, chicken fillet samples treated by vacuum packaging were in the range of permissible level of TBA as reported by E.O.S. (2005), which recommends that TBA content in frozen samples not exceed $0.900 \mathrm{mg}$ malonaldehyde/kg sample. Also, the sample stored at cold temperature was within safe limits until the end of storage period $(0.870$ $\mathrm{mg} / \mathrm{kg}$ ) as shown in Table (2). While, different control samples and samples treated by aerobic packaging at these previous periods were spoiled.

\section{Effect of some hurdle technology methods on $\mathrm{pH}$ value for chicken fillets during storage:}

The $\mathrm{pH}$ value is considered an important factor because of its influence on shelf-life, color, water holding capacity and texture of meat and meat products (Clarke et al., 1988).

Data presented in Table (3) showed the changes in $\mathrm{pH}$ values of both control and treated chicken fillet samples as affected by tested hurdle technology methods and different packaging with extended storage periods. From the Table, it could be noticed that significant differences $(\mathrm{P}<0.05)$ in $\mathrm{pH}$ values between control sample and the samples treated by aerobic packaging or vacuum packaging at initial storage. The control sample recorded $\mathrm{pH}$ 5.64 , while treated samples recorded $\mathrm{pH}$ values from 4.49 to 4.52 .

As noted no significant differences between the samples treated by aerobic packaging and vacuum packaging at the same conditions up to $3^{\text {th }}$ day storage at room temperature, $15^{\text {th }}$ day of cold storage and $60^{\text {th }}$ day of frozen storage.

As shown in Table (3), the treatment of chicken fillet samples by different packaging methods resulted in a great reduction $(\mathrm{P}<0.05)$ of $\mathrm{pH}$ values when compared with $\mathrm{pH}$ values of three control samples during storage periods. It may be because of the acidic effect of treatment solution which contains lactic acid and sorbic acid.

On the other hand, $\mathrm{pH}$ values continuously increased $(P<0.05)$ in all tested samples with prolongation of different storage periods. The increment rates in values were decreased with treatment of chicken fillet samples by vacuum packaging. Generally, these results are in agreement with those obtained by Sheshrao (2005) and Tanuvas (2014).

Also, significant differences $(\mathrm{P}<0.05)$ in $\mathrm{pH}$ values were observed between the samples treated by aerobic packaging and vacuum packaging starting from sixth day storage at room temperature, fifteenth day of cold storage and sixty day of frozen storage.

It is worth mentioning that $\mathrm{pH}$ values of the samples treated by vacuum packaging, after 18 days storage at room temperature was 7.34, after 135 days of cold storage was 7.09 and after 180 days of frozen storage was 7.10. While, control samples and samples treated by aerobic packaging at these previous periods were spoiled, as shown in Table (3). 
Finally, it is apparent from previous results that the treatment of chicken fillets by some hurdle technology methods retarded the development of rancidity in the samples at the different storage conditions compared to the control samples (without treatment). Also, it could be observed that the vacuum packaging showed the best protection towards reducing the values of TVBN, TBA and $\mathrm{pH}$ in chicken fillet samples during different storage periods in comparison with aerobic packaging.

Effect of some hurdle technology methods on frying losses for chicken fillets during storage:

Data presented in Table (4) showed the changes in frying losses (\%) of both control samples and treated samples as affected by some hurdle technology methods and different packaging with extended storage periods. data indicated that no significant differences in frying loss values between control sample and the samples treated by aerobic packaging or vacuum packaging at initial storage.

The frying loss of control sample was $12.78 \%$, while treated samples recorded values from 12.77 to $12.81 \%$. On the same context, noted no significant differences between the samples treated by aerobic packaging and vacuum packaging at the same conditions up to $3^{\text {th }}$ day storage at room temperature, $15^{\text {th }}$ day of cold storage and zero time of frozen storage.

As shown in Table (4), the treatment of chicken fillet samples by different packaging methods resulted in considerable increase $(\mathrm{P}<$ $0.05)$ in frying loss values when compared with values of control samples during storage periods.

On the other hand, frying loss values continuously increased $(\mathrm{P}<0.05)$ in all tested samples with prolongation of different storage periods. The increment rates in values were decreased with treatment of the samples by vacuum packaging (losses \% was ranged from $12.90 \%$ after 30 days of frozen storage to $14.09 \%$ after 135 days of cold storage). While, the largest losses were observed in the different control samples (from $12.97 \%$ after 30 days of frozen storage to $13.45 \%$ after 3 days only of room storage).

Also, significant differences $(\mathrm{P}<0.05)$ in frying loss values were observed between the samples treated by aerobic packaging and vacuum packaging starting from sixth day storage at room temperature, forty-fifth day of cold storage and thirty day of frozen storage.

It is worth mentioning that frying loss values of samples treated by vacuum packaging, after 18 days storage at room temperature was $13.77 \%$, after 135 days of cold storage was $14.09 \%$; and after 180 days of frozen storage was $13.56 \%$. While, control samples and the samples treated by aerobic packaging at these previous periods were spoiled, as shown in Table (4).

\section{Effect of some hurdle technology methods on color for chicken fillets during storage:}

Data presented in Table (5) showed the changes in color of both control samples and treated chicken fillet samples as affected by some hurdle technology methods and different packaging with extended storage periods. From the Table, it could be noticed no significant differences in color values between control sample and samples treated by aerobic packaging or vacuum packaging at initial storage. $\Delta \mathrm{E}$ value for control was 38.10 , while the treated samples recorded values from 37.82 to 38.10. On the same context, noted no significant differences between samples treated by aerobic packaging and vacuum packaging at the same conditions up to $15^{\text {th }}$ day of cold storage and $90^{\text {th }}$ day of frozen storage.

Also, from Table (5), it could be observed that color values of all samples were gradually increased $(\mathrm{P}<0.05)$ during storage periods under different packaging conditions. The different control samples showed the highest $(\mathrm{P}<0.05)$ values of color at the end of each storage period compared with treated samples.

Where, color value $(\Delta \mathrm{E})$ of control sample stored at room temperature increased from 38.10 to 40.92 after 3 days and chicken fillet sample treated by aerobic packaging increased from 38.19 to 42.92 after 12 days, while treated sample by vacuum packaging increased from 37.82 to 41.21 after 18 days. Also, the other samples stored at cold and frozen temperatures were encountered the same trend. Color values in treated samples by aerobic packaging and vacuum packaging reached to 41.42 and 41.85 , respectively after 75 and 135 days of cold storage, and 41.02 and 41.16 after 120 and 180 days of frozen storage as shown in Table (5).

It should be noted that there are significant differences $(\mathrm{P}<0.05)$ between the samples treated by aerobic packaging and the samples treated by vacuum packaging from beginning the $3^{\text {th }}$ day of storage at room temperature, $15^{\text {th }}$ day of cold storage and $120^{\text {th }}$ day of frozen storage until the end of storage stages. Generally, these results are similar with the results of Malik and Sharma (2011), Alahakoon et al. (2014) and Tanuvas (2014). They found that the color values of meat and chicken fillet were 
affected by tested hurdles technology treatment and vacuum packaging. These values were increased by increasing storage periods.

\section{Effect of some hurdle technology methods on microbiological quality criteria for chicken fillets during storage:}

\section{Total bacterial count (TBC):}

Total bacterial count of any food product is significantly correlated directly with the sanitary conditions of processing, handling and storage conditions. The microbial activity leads to certain changes in flavour, color and accumulation of toxin in meat (Fliss et al., 1991 and Osheba, 2003).

From the results in Table (6), it could be noticed that total bacterial counts (TBC) of tested chicken fillet samples were influenced by tested hurdle technology methods and different packaging during storage periods at room temperature, cold temperature and frozen temperature.

The results showed that TBC of chicken fillet samples treated by aerobic packaging or vacuum packaging were lower than control sample at initial storage. TBC of control sample was $1.83 \log \mathrm{cfu} / \mathrm{g}$, while samples treated by aerobic packaging recorded TBC from 1.65 to $1.77 \log \mathrm{cfu} / \mathrm{g}$ and the samples treated by vacuum packaging recorded TBC from 1.63 to $1.76 \log \mathrm{cfu} / \mathrm{g}$ under the same conditions. Generally, these results are in agreement with those obtained by Haridas (2006) and El daly et al. (2018), who found that the microbial load in chicken fillet samples decreased with using hurdles technology treatment.

On the other hand, TBC linearly increased with progressing the storage periods for all tested samples, especially control samples were different as compared with the other samples. Moreover, after 9 days storage at room temperature, 75 day of cold storage and 90 day of frozen storage, the samples treated by aerobic packaging were in the range of permissible level as reported by E.O.S. (2005), which recommends that the total bacterial in frozen samples not exceed $4 \log \mathrm{cfu} / \mathrm{g}$. Also, the samples treated by vacuum packaging after 15 day storage at room temperature, 135 day of cold storage and 150 day of frozen storage were within permissible counts. While, different control samples at these previous periods were spoiled as shown in Table (6). This might be due to slight increasing for nitrogen compound (such as amino acid) and produced fatty acids by hydrolysis of protein and fat during storage, consequently lead to suitable conditions for growth of microorganisms (Wally, 2002). Generally, these results are consistent with findings of Kacaniova et al. (2019). They reported that the hurdles technology treatments may be an effective strategy to control in many microorganisms.

\section{Psychrophilic bacterial count:}

Many psychrophilic bacteria when presented in large numbers can cause a variety of off-flavour as well as physical defects in food (Gilliland et al., 1976). Psychrotrophic organisms are primarily responsible for spoilage of poultry, meat and seafood products. Freezer temperature is sufficient to prevent the growth of all microorganisms, but some can grow within the freezer range at an extremely show rate (Jay, 1986).

The effect of some hurdle technology methods and different packaging on psychrophilic bacteria for chicken fillet samples during storage periods at different temperatures were illustrated in Table (7). It is normal that psychrophilic bacteria are not present in chicken fillet samples at initial storage or stored at room temperature for different periods.

Noteworthy is that hurdles technology treatment resulted in decrease of psychrophilic bacteria count in treated samples when compared with control samples starting from $15^{\text {th }}$ day of cold storage and $30^{\text {th }}$ day of frozen storage. Psychrophilic bacteria count in the samples treated by aerobic packaging and vacuum packaging reached 1.88 and $1.71 \mathrm{log}$ cfu /g, respectively, after 75 days of cold storage; 1.89 and $1.77 \log$ cfu /g after 120 days of frozen storage. While, the control samples on these previous periods were spoiled. In this concern, Rathod et al. (2019) investigated that the hurdles technology treatment may be an effective strategy to control in many microorganisms. Generally, these results are in agreement with those obtained by Abdel daiem et al. (2014), who found that the microbial load in chicken meat samples decreased with using tested hurdles technology.

Regarding the activity of psychrophilic bacteria during storage, psychrophilic bacteria count continuously increased in all tested samples with prolongation of storage periods. It is worth mentioning that on the end of cold or frozen storage periods, vacuum packaging was the most effective in reducing psychrophilic bacteria count. Psychrophilic bacteria count of these samples reached after 135 days of cold storage and 180 days of frozen storage 2.24 and $1.93 \log \mathrm{cfu} / \mathrm{g}$, respectively as shown in Table 
(7). While, the control and samples treated by aerobic packaging on the previous periods were spoiled.

Generally, at $90^{\text {th }}$ day of cold storage, the samples treated by vacuum packaging were within permissible counts as reported by E.O.S. (2005), which recommends that the psychrophilic bacteria counts in frozen samples not exceed $2 \log \mathrm{cfu} / \mathrm{g}$. Also, the samples stored at frozen temperature were within permissible counts even after the storage period is finished.

\section{Coliform group bacteria count:}

From the results in Table (8), it could be noticed that coliform group bacterial counts of chicken fillet samples were influenced by tested hurdles technology treatment and different packaging methods during storage periods at room temperature, cold temperature and frozen temperature.

The Table showed that coliform group bacterial counts of samples treated by aerobic packaging or vacuum packaging were lower than control sample at initial storage. Coliform group bacterial count of control sample was $1.21 \mathrm{log}$ cfu /g, while samples treated by aerobic packaging recorded counts from 1.18 to $1.20 \mathrm{log}$ $\mathrm{cfu} / \mathrm{g}$ and the samples treated by vacuum packaging recorded counts from 1.18 to $1.19 \mathrm{log}$ cfu /g under the same conditions. Generally, these results are in agreement with those obtained by El daly et al. (2018), who found the coliform group bacterial count in tested chicken fillet samples decreased with using hurdles technology treatment.

Noteworthy that the tested hurdles technology treatment resulted in decrease of coliform group bacterial counts in treated chicken fillet samples when compared with control samples starting from $3^{\text {th }}$ day of room storage, $15^{\text {th }}$ day of cold storage and $30^{\text {th }}$ day of frozen storage.

Coliform group bacterial counts in the samples treated by aerobic packaging and vacuum packaging reached 2.09 and $1.72 \mathrm{log}$ cfu $/ g$, respectively after 12 days of room storage, 1.97 and $1.70 \log$ cfu /g after 75 days of cold storage; and 1.92 and 1.69 log cfu /g after 120 days of frozen storage. While, the control samples on these previous periods were spoiled. These results are in agreement with those obtained by Haridas (2006), who found that the microbial load in chicken curry samples decreased with using tested hurdles technology treatment. In this concern, Gertzou et al. (2017) and Rathod et al. (2019) investigated that the hurdles technology treatments may be an effective strategy to control in many microorganisms. Generally, these results are in agreement with those obtained by Abdel daiem et al. (2014), who found that coliform group bacterial count in chicken meat samples decreased with using hurdles technology.

On the other hand, coliform group bacteria counts linearly increased in all tested samples with prolongation of storage periods. At the end of storage periods on room temperature, cold temperature and frozen temperature, the vacuum packaging method was the most effective in reducing coliform group bacteria counts. Hence, coliform group bacteria count for these samples reached to $2.10 \mathrm{log}$ cfu /g after 18 days of storage on room temperature, 2.09 $\log \mathrm{cfu} / \mathrm{g}$ after 135 days of cold storage and 1.87 $\log \mathrm{cfu} / \mathrm{g}$ after 180 days of frozen storage, as shown in Table (8). While, the control and samples treated by aerobic packaged on the previous periods were spoiled. This might be due to slight increasing for nitrogen compound (such as amino acid) and produced fatty acids by hydrolysis of protein and fat during storage, consequently lead to suitable conditions for growth of microorganisms (Wally, 2002).

Generally, after 9 and 15 days of storage at room temperature, as well as after 75 and 105 days of storage at cold temperature, the chicken fillet samples treated by aerobic and vacuum packaging were within permissible counts as reported by E.O.S. (2005), which recommends that the coliform group bacteria counts in frozen samples not exceed $2 \log \mathrm{cfu} / \mathrm{g}$. Also, the treated samples stored at frozen temperature were within permissible counts even after the storage periods are finished.

\section{Mold and yeast counts:}

The presence of yeasts and molds in food items may constitute a public health hazards as they may produce some toxic substance which are considered harmful to human (Shan et al., 2007).

The effect of some hurdle technology methods and different packaging on mold and yeast counts for chicken fillet samples during storage periods at different temperatures was illustrated in Table (9).

The results showed that the mold and yeast counts of samples treated by aerobic packaging or vacuum packaging were lower than control sample at initial storage. The mold and yeast counts of control sample was $1.18 \mathrm{log} \mathrm{cfu} / \mathrm{g}$, while samples treated by aerobic packaging recorded counts from 1.07 to $1.15 \mathrm{log}$ cfu /g, and the samples treated by vacuum packaging 
recorded counts from 1.07 to $1.14 \mathrm{log} \mathrm{cfu} / \mathrm{g}$ at the same storage conditions. Generally, these results are in agreement with Haridas (2006) and El daly et al. (2018), who found that the microbial load in chicken fillet samples decreased with using tested hurdles technology treatment.

The tested hurdle technology treatment resulted in decrease of mold and yeast counts in treated chicken fillet samples when compared with control samples starting from $3^{\text {th }}$ day of room storage, $15^{\text {th }}$ day of cold storage and $30^{\text {th }}$ day of frozen storage. The mold and yeast counts in samples treated by aerobic packaging and vacuum packaging reached to 1.69 and 1.50 $\log \mathrm{cfu} / \mathrm{g}$, respectively, after 12 days of room storage, 1.97 and $1.67 \mathrm{log} \mathrm{cfu} / \mathrm{g}$ after 75 days of cold storage; 1.89 and 1.78 log cfu /g after 120 days of frozen storage. While, the control samples on these previous periods were spoiled. These results are in agreement with obtained by Haridas (2006), who found the microbial load in chicken curry samples that decreased with using hurdles technology treatments. In this concern, Gertzou et al. (2017) and Rathod et al. (2019) investigated that the hurdles technology treatments may be an effective strategy to control in many microorganisms. Generally, these results are in agreement with those obtained by Abdel daiem et al. (2014), who found that the mold and yeast counts in chicken meat samples decreased with using hurdles technology.

On the other hand, mold and yeast counts linearly increased in all tested samples with prolongation of storage periods. At the end of storage periods under room, cold and frozen temperatures, the vacuum packaging method was the most effective in reducing mold and yeast counts. Hence, the counts of these samples reached to $1.79 \log \mathrm{cfu} / \mathrm{g}$ after 18 days of storage on room temperature, $2.04 \mathrm{log} \mathrm{cfu} / \mathrm{g}$ after 135 days of cold storage and $1.96 \mathrm{log} \mathrm{cfu} / \mathrm{g}$ after 180 days of frozen storage, as shown in Table (9). While, the control and samples treated by aerobic packaged on the previous periods were spoiled.

Generally, all tested samples stored at room, cold and frozen temperatures were within permissible counts even after the storage periods are finished as reported by E.O.S. (2005), which recommends that the mold and yeast counts in frozen samples not exceed $2 \mathrm{log}$ $\mathrm{cfu} / \mathrm{g}$. With the exception, the sample treated by vacuum packaging and stored on cold temperature for 135 days, as well as the freezing control sample for 90 days were exceeded the permissible counts.

\section{Anaerobic bacteria counts:}

From the results in Table (10), it could be noticed that anaerobic bacteria count of chicken fillet samples was influenced by tested hurdle technology treatment and vacuum packaging method during storage at different temperatures.

The Table showed that anaerobic bacteria counts of samples treated by vacuum packaging were 1.02, 0.94 and $0.90 \mathrm{log}$ cfu /g at initial storage on room, cold and frozen temperatures.

On the other hand, anaerobic bacteria counts incrementally increased in all tested samples with prolongation of storage periods. The samples increased from 1.02 to $2.04 \mathrm{log} \mathrm{cfu} / \mathrm{g}$ after 18 days storage at room temperature, from 0.94 to $1.99 \mathrm{log}$ cfu /g after 135 days of cold storage and from 0.90 to $1.79 \mathrm{log} \mathrm{cfu} / \mathrm{g}$ and after 180 days of frozen storage, as shown in Table (10). Generally, all tested samples stored at room, cold and frozen temperatures were within permissible counts even after the storage periods are finished as reported by E.O.S. (2005), which recommends that the anaerobic bacteria counts in frozen chicken products not exceed $2 \log \mathrm{cfu} / \mathrm{g}$. With the exception, the sample stored at room temperature for 18 days was exceeded the permissible level. Generally, these results are in agreement with those obtained by Chouliara et al. (2007) ; Malik and sharma (2011), they found that the anaerobic bacteria counts in meat chicken samples decreased with using tested hurdle technology.

\section{Staphylococcus aureus, Clostridium spp., Salmonella and Shigella counts:}

The effect of some hurdle technology methods and different packaging on counts of Staphylococcus aureus, Clostridium spp., Salmonella and Shigella for chicken fillet samples during storage at different temperatures was studied.

It could be noticed that Staphylococcus aureus, Clostridium spp., Salmonella and Shigella not detected in all samples either at zero time or during storage periods at different temperatures. This might be due to hygienic processing practices and / or the microbial effect of hurdles technology (El daly et al., 2018).

Generally, these results agree with those obtained by Juneja et al. (2005), who recorded the absence of clostridium spp., S. aureus and Salmonella spp. in tested chicken meat samples even after storage. Also, Abd El-Qader (2004) and Mohamed (2011) found that the chicken fillet and burger samples treated by volatile oils 
of some spices were free from Salmonella spp. at any storage period.

Finally, it is apparent from previous results that using of some hurdle technology methods impeded the growth of tested microorganisms in the treated samples. Also, it could be observed that the vacuum packaging showed the best activity towards reducing the counts of these microorganisms in samples during storage periods in comparison with examined aerobic packaging.

\section{Effect of some hurdle technology methods on sensory quality criteria for chicken fillets during storage:}

Sensory evaluation is an important factor in judging about foodstuffs quality. Also, consumer is a major factor for selecting a product and among the main characteristics related to quality are surface color, odor, taste and texture of final product (Pereira et al., 2013 and Akesowan, 2015). Sensory evaluation together with estimation the former physical, chemical and microbiological criteria have been used extensively to assess the quality of meat products.

Based on chemical, physical and microbiological studies, cooked chicken fillet samples that exceeded the maximum permissible levels in microbial load, TVN and TBA were excluded from the sensory evaluation.

Therefore, cooked samples treated by tested hurdle technology were evaluated for sensory properties and compared with control samples (without treatment) either at zero time or during each storage period as shown in Table (11).

Data show that there were significant differences $(P<0.05)$ observed among tested chicken fillet samples and control sample in taste, color, odor, juiciness and tenderness at initial storage. The control sample recorded judging scores from 9.2 to 9.3 for all tested organoleptic quality properties, while treated samples recorded values from 8.0 to 8.7. Also, the same Table showed that there were no significant differences occurred between the samples treated by aerobic packaging and vacuum packaging in all sensory characteristics at the same conditions. Moreover, the samples treated by aerobic packaging showed judging scores similar to samples treated by vacuum packaging in taste, color and odor at initial cold storage (8.1 for both of them).

With regard to the overall acceptability, Table (11) showed that there were significant differences $(P<0.05)$ observed among treated samples and control sample in overall acceptability at initial storage. The control sample recorded judging score 9.1, while treated samples recorded values from 8.1 to 8.5. At the same time, no significant differences were observed between the samples treated by aerobic packaging and vacuum packaging (judging scores 8.1 and 8.3, respectively) in overall acceptability at initial room storage. While, judging scores were similar between these two samples under cold storage (8.2) and frozen storage (8.5).On the other hand, the samples treated by different packaging methods showed higher $(\mathrm{P}<0.05)$ or similar judging scores in all tested organoleptic quality properties than control samples during the storage periods as shown in Table (11). With exception, at $15^{\text {th }}$ day of cold storage and $30^{\text {th }}$ day of frozen storage, the control samples showed higher $(\mathrm{P}<0.05)$ judging scores in all tested organoleptic quality properties than treated samples. While, at $3^{\text {th }}$ day of room storage, the control sample was lowest $(\mathrm{P}<0.05)$ acceptable compared with the other samples.

It is worth noting that there were significant differences $(\mathrm{P}<0.05)$ occurred between samples treated by aerobic packaging and vacuum packaging in all tested organoleptic properties until the end of storage periods. Except for those samples stored on cold temperature at 15 and 30 days were not differed in taste, color, odor, juiciness and tenderness. Also, the samples stored on frozen temperature at 30 and 60 days were not differed in tenderness and juiciness.

Also from the present results in Table (11), after 9 days of room storage, 75 days of cold storage and 120 days of frozen storage, the tested organoleptic quality properties for samples treated by vacuum packaging were higher $(P<0.05)$ than samples treated by aerobic packaging.

Regarding to the overall acceptability for tested samples during storage, observed significant differences $(\mathrm{P}<0.05)$ between treated samples and control samples until the end of storage periods. At the same time, no significant differences were observed between the samples treated by aerobic packaging and vacuum packaging up to $45^{\text {th }}$ day of cold storage and $60^{\text {th }}$ day of frozen storage. While, the situation differed in storage at room temperature, the samples treated by aerobic packaging differed significantly $(\mathrm{P}<0.05)$ with samples. 
Generally, data of sensory tests for the cooked chicken fillet samples agree with observed in studies of Berwal et al. (2013), Alahakoon et al. (2014) and Rindhe et al. (2017), they found that the tested hurdles technology treatment and vacuum packaging had a high sensory acceptability for all produced chicken meat samples.

Finally, it can be concluded that the samples treated by vacuum packaging exhibited a desired good sensory quality properties and better acceptability when compared with control sample and samples treated by aerobic packaging even after frozen storage for 5 months.CONCLUSION

It could be concluded that the using of some hurdle technology methods retarded the development of rancidity and impeded the growth of microorganisms in chicken fillet samples at the different storage conditions compared to the control samples. Also, it could be observed that the vacuum packaging showed the best protection towards reducing the values of TVBN, TBA and $\mathrm{pH}$, as well as maintaining good sensory quality properties in tested samples during storage periods in comparison with aerobic packaging.

\section{REFERENCES}

A.M.S.A, 1995. Research guidelines for cookery, sensory evaluation and instrumental tenderness measurements of fresh beef. American Meat Science Assoc., Chicago, U.S.A.

A.P.H.A., 1976. American Public Health Association, Compendium of Methods for the Microbiological Examination of Foods. Speck, M.L. ed., Washington D.C., U.S.A.

Abd El-Qader, M.F., 2004. Quality Improvement of Chicken Frozen Burger Formulated with Some Spices or their Volatile Oils. M.Sc. Thesis, Fac. Agric., Cairo Univ.

Abdeldaiem, M.H., 2014.Using of combined treatment between edible coatings containing ethanolic extract of papaya (Carica Papaya L.) leaves and gamma irradiation for extending shelflife of minced chicken meat. Am. J. Food Sci. Technol., 2. (1), 6-16.

Akesowan, A. 2015., Optimization light pork burgers formulated with canola oil and linseed/sun flower seed/almond (LSA) mix. J. Anim. Plant Sci., 25 (1), 268-277.

Alahakoon, A.U., Jayasena, D.D., Jung, S., Kim, H.J., Kim., S.H., Jo, C., 2014. Antimicrobial effect of calcium chloride alone and combined with lactic acid injected into Chicken breast meat. Korean J. Food Sci. Resour. 34, (2), 221:229.

Bazargani-Gilani, B., Aliakbarlu, J., Tajik, H., 2015. Effect of pomegranate juice dipping and chitosan coating enriched with Zataria multiflora Boiss essential oil on the shelflife of chicken meat during refrigerated storage. Innov. Food Sci. Emerg. Technol. 29, 280-287.

Berwal, R.K., Khanna, N., Berwal R., 2013. Storage quality of chicken meat mince incorporated cookies under aerobic packaging at ambient temperature. J. Meat Sci. Technol. 1. (1), 28-34.

Bolumar, T., Andersen, M.L., Orlien, V., 2011. Antioxidant active packaging for chicken meat processed by high pressure treatment. Food Chem., 129, 1406-1412.

Chouliara, E., Karatapanis, A., Savvaidis, I.N., Kontominas, M.G., 2007. Combined effect of oregano essential oil and modified atmosphere packaging on shelf-life extension of fresh chicken breast meat, stored at 4C. Food Microbiol., 24, 607-617.

Clarke, A.D., Sofos, J.N., Schmidt, G.R., 1988. Effect of algin/calcium binder levels on various characteristics of structured beef. J. Food Sci., 53, 711-713.

Davies, A., Board, R., 1998. The physiological attributes of gram negative bacteria associated with, spoilage of meat and meat products. In: The Microbiology of Meat and Poultry. Elsevier: Blackie Academic and Professional, London, UK, pp. 1-28.

Difco-Manual 1984. Dehydrated culture media and reagents microbiological and clinical laboratory procedures, Pub. Difco-lab-Detroits Michigan, U.S.A.

Dogan, S.F., Serpil, S.S., Sumnu, G., 2005. Effects of batters containing different protein types on the quality of deep-fat-fried chicken meat nuggets. Eur. Food Res. Technol., 220, 502-508.

E.O.S., 2005. Products Of Meat Poultry Treated With Heat. Egyptian Organization for Standardization and quality Control, Ministry of Industry and Trade. Egypt, No 3493.

El-Akel, A.T.M., 1988. Chemical, Microbiological and Sensory Evaluation of Hot Smoked Catfish. Ph.D. Thesis, Food Science and Technology Dept., Faculty of Agric., Cairo Univ. Egypt.

Eldaly, E.A., Mahmoud, A.F.A., Abobakr, H.M., 2018. Preservative effect of chitosan coating on shelf life and sensory properties of chicken fillets during chilled storage. J. Nutr. Food Secur., 3 (3), 139-148.

FAO, 1979. Manuals of Food-Quality Control, 4, Microbiological analysis. Food and Agriculture Organization of the United Nations, Rome, pp9 - 12 on Di-133.

Fliss, L., Sinard, R.E., Ettriki, A., 1991. Composition of three sampling techniques for microbiological analysis of meat science. J. Food Sci., 56, 249-260.

Gayán, E., Torres, J.A., Paredes-Sabja, D., 2012. Hurdle approach to increase the microbial 
inactivation by high pressure processing: effect of essential oils. Food Eng. Rev. 4, 141148.

Gertzou, I.N., Karabagias, I.K., Drosos, P.E., Riganakos, K.A., 2017. Effect of combination of ozonation and vacuum packaging on shelf life extension of fresh chicken legs during storage under refrigeration. J. Food Eng., 213, 18-26.

Gilliland, S.E., Michener, H.D., Kraft, A.A., 1976. Psychrotrophic microorganisms. In: Compendium of Methods for Microbiological Examination of Food, Am. Public Health Assoc. Inc. Washington, D.C., USA, pp- 173-178.

Gould, G.W., 1995. Homeostatic mechanisms during food preservation by combined methods. In Barbosa-Cánovas, G.V., WeltiChanes, J., Eds., Food Preservation by Moisture Control, Fundamentals and Applications, Lancaster, PA: Technomic Publishing Co., Inc., pp. 397-410.

Haridas, D.A., 2006. Process Optimization of Ready to Eat Chicken Curry Using Hurdle Technology. M.Sc. Thesis, Livestock Product Tech Dept., Faculty of Veterinary and Animal Sciences. Nagpur Univ., India.

Hashem, H.A., Shaheen, A., El-Damaty, E.M., ElDushloty, M.S., Ameen, M.A., 1978. Quality indices and bacteriological changes occurring in sausage as prepared with meal. Substitutes of plant origin. Egypt. J. Food Sci., 6 (1-2), 83-90.

Hassanzadeha, P., Tajikb, H., Rohanib, S.M.R., Moradib, M., Hashemic, M., Aliakbarlu, J., 2017. Effect of functional chitosan coating and gamma irradiation on the shelf-life of chicken meat during refrigerated storage. Radiat. Phys. Chem., 141, 103-109.

Jafari, N.J., kargozari, M., Ranjbar, R., Rostami, H., 2017. The effect of chitosan coating incorporated with ethanolic extract of propolis on the quality of refrigerated chicken fillet. Food Proc. Preserv., 10, 1-8.

Jay, J.M., 1986. Modern Food Microbiology. 2nd Ed., Van Nastrand Rienhold Company Inc., USA, p. 664.

Juneja, V.K., Fan, X., Peña-Ramos, A., Diaz-Cinco, M., Pacheco-Aguilar, R., 2005. The effect of grapefruit extract and temperature abuse on growth of Clostridium perfringens from spore inocula in marinated, sous-vide chicken products. Innov. Food Sci. Emerg. Technol., 7, 100-106.

Ka cániová, M., Mellen, M., Vukovic, N.L., Kluz. M., Puchalski, C, Haš cík, P., Kunová, S., 2019. Combined effect of vacuum packaging, fennel and savory essential oil treatment on the quality of chicken thighs. Microorganisms, 7, 134-144.

Leistner, L., 1995. Use of hurdle technology in food processing: recent advances. In: Food Preservation by Moisture Control, Fundamentals and Applications, Barbosa-
Cánovas G.V., Welti-Chanes, J., Ed., Technomic Publishing Co., Inc., Lancaster, PA pp. 377-369.

Leistner, L., 2000. Hurdle technology in the design of minimally processed foods. In: Alzamora, S.M., Tapia, M.S., López-Malo, A., Ed., Minimally Processing Fruits and Vegetables Aspen Publishers, Inc., Gaithersburg, MD: pp. 13-27.

Malik, A.H., Sharma, B.D., 2011. Comparison of hurdle treatments for buffalo meat. Int. J. Food Sci. Technol. 45, 1552-1563.

Melton, S.L., 1983. Methodology for following lipid oxidation muscle Foods. J. Food Technol., 37 (6), 105-111.

Mery, D., Pedreschi, F., Leon, J., 2006. Color measurement in $L^{*} a^{*} b^{*}$ units from RGB digital images, Food Res. Int. 39. 1084-1091.

Moawad, R.K., 1995. Effect of Pretreatment on Quality Attributes and Nutritive Value of Frozen Beef and Chicken Meats. Ph.D. Thesis, Food Science and Technology Dept., Faculty of Agric., Cairo Univ.

Mohamed, R.A.A., 2011. Chemical and Microbiological Studies on Some Chicken Meat Products. M.Sc. Thesis, Fac. Agric., Assiut Univ.

Mwansyemela, N.A., 1973. Report on studies of routine analysis for food chemistry. Institute for fishery products TNO at Ijmuiden, Holland, 2nd April to 15th Sept.

Ntzimani, A.G., Giatrakou, V.I., Savvaidis, I.N., 2010. Combined natural antimicrobial treatments (EDTA, lysozyme, rosemary and oregano oil) on semi cooked coated chicken meat stored in vacuum packages at $4{ }^{\circ} \mathrm{C}$ : Microbiological and sensory evaluation. Innov. Food Sci. Emerg. Technol. 11, 187-196.

Osheba, A.S. 2003. Studies on the Preparation of Some Healthy Foods. Ph.D. Thesis, Fac. Agric., Minufiya Univ., Shebin El-Kom, Egypt.

Pal, M., Gebretensey, A., Shiberu, T., Abdurahman, M., Karanfil, O., 2014. The role of bacteriosin as food preservative. Beverage Food World 42, 2830.

Pereira, O.R., Marcias, R.I.R., Perez, M.J., Marin, J.J.G., Cardoso, S.M., 2013. Protective effects of phenolic constituents from Cytisus multiflorus, Lamium album L. and Thymus citriodorus on liver cells J. Func. Foods, 5, 1170-1179.

Petrou, S., Tsiraki, M., Giatrakou, V., Savvaidis, I., 2012. Chitosan dipping or oregano oil treatments, singly or combined on modified atmosphere packaged chicken breast meat. Int. J. Food Microbiol., 156 (3), 264-271.

Pundir, A., Murtaza, N., 2015. Hurdle technology: An approach toward food preservation. Int. J. Curr. Microbiol. Appl. Sci. 4: 802-809.

Rathod, K.S., Pawade, A.A., Ambadkar, R.K., 2019. Storage Stability of Chicken Momo at Super 
Chilling Temperature. Int. J. Curr. Microbiol. Appl. Sci., 7 (12), 3154-3164.

Rindhe, S.N., Shinde, A.T., Jadhav, B.A., Kumbhar, V.H., 2017. Application of hurdle technology for preservation of chicken sausages at ambient temperature (37 \pm 10 c), Int. J. Pure App. Biosci., 5 (4), 480-488.

Rosete-Hidalgo, H.J., Sosa, M.M.E., Cenkowski, S., Velez, R.J.F., 2008. Superheated steam as pretreatment to reduce oil uptake during deep frying of chicken meat nuggets. Ann. Conf. Vancouver, Canada, July 13 - 16, 108 -199.

Shan, B., Cai, Y., Brooks, J.D., Corke, H., 2007. The in vitro antibacterial activity of dietary spice and medicinal herb extracts. Int. J. Food Microbiol., 117, 112-119.

Sheshrao, R.K., 2005. Application of hurdle technology for preservation of ready to eat chicken curry. M.Sc. Thesis, livestock product tech Dept., Faculty of veterinary and animal sciences. Nagpur Univ. India.

Snedecor, G.W., Cochran, W.G., 1994. Statistical Methods, 8th Ed. Oxford and IBH Pub. New Delhi.

Tanuvas, K.A., 2014. Extension of Shelf Life of Chicken Meat Patties using Natural Preservatives by Application of Hurdle Technology. Ph.D. Thesis, Tamil Nadu Veterinary, Faculty of veterinary and animal sciences Univ. India.
Tarladgis, B.G., Watts, B.M., Younathan, M.T., Dugan, L., 1960. A distillation method for the quantitative determination of malonaldehyde in rancid food, J. Am. Oil. Chem. Soc., 37, 44-48.

Totosaus, A., Kuri, V., 2007. Packaging of fresh and frozen poultry, in Nollet L.M.L., Ed., Handbook of Meat, Poultry \& Seafood Food Products, Blackwell, Oxford, pp. 475485.

Twig, G., Your, E.P., Kitul, A.W., 1976. Evaluation of beef patties containing soy protein during 12 month frozen storage. J. Food Sci., 41, 11421147.

Vareltzis, K., Koufidis, D., Gavrülidou, E., Papavergou, E., Vasiliadou, S., 1997. Effectiveness of a natural rosemary (Rosmarinus officinalis) extract on the stability of filleted and minced fish during frozen storage. Z. Lebensm. Unters. Forsch. A., 205, 93-96.

Viana, E.S., Gomide, L.A.M., Vanetti, M.C.D., 2005. Effect of modified atmospheres on microbiological, color and sensory properties of refrigerated pork. Meat Sci., 71, 696-705.

Wally, F.A.A. 2002. Studies on Quality Attributes of some Semi-fried Chicken Products during Frozen Storage. Ph.D. Thesis, Fac. of Agric., Cairo Univ., Egypt.

Younathan, M.T., Marjan, Z.M., Arshad, F.B., 1980. Oxidative rancidity in stored ground turkey and beef. J. Food Sci., 46, 274-279. 
Table 1. Effect of some hurdles technology on Total volatile bases nitrogen (TVBN) content ( $\mathrm{mg} \mathrm{N}_{2} / 100 \mathrm{~g}$ ) of chicken fillet samples storage at different conditions:

\begin{tabular}{|c|c|c|c|c|c|c|c|c|c|c|c|}
\hline \multicolumn{4}{|c|}{ Storage at room temperature $\left(25 \pm 5 \mathrm{C}^{\circ}\right)$} & \multicolumn{4}{|c|}{ Storage at cold temperature $\left(4 \pm 2 \mathrm{C}^{\circ}\right)$} & \multicolumn{4}{|c|}{ Storage at frozen temperature $\left(-18 \pm 2 \mathrm{C}^{\circ}\right)$} \\
\hline Treatment & & & & Treatment & & & & Treatmen & & & \\
\hline $\begin{array}{l}\text { Storage } \\
\text { (day) }\end{array}$ & Control & A.P & V.P & $\begin{array}{l}\text { Storage } \\
\text { (day) }\end{array}$ & Control & A.P & V.P & $\begin{array}{c}\text { Storage } \\
\text { (day) }\end{array}$ & Control & A.P & V.P \\
\hline 0 & $2.84^{\mathrm{Ab}}$ & $2.57^{\mathrm{Be}}$ & $2.54^{\mathrm{Bh}}$ & 0 & $2.84^{\mathrm{Ab}}$ & $2.41^{\mathrm{Bf}}$ & $2.21^{\mathrm{Cj}}$ & o & $2.84^{\mathrm{Ad}}$ & $2.48^{\mathrm{Be}}$ & $2.38^{\mathrm{Cg}}$ \\
\hline 3 & $19.56^{\mathrm{Aa}}$ & $9.17^{\mathrm{Bd}}$ & $5.74^{\mathrm{Cg}}$ & 15 & $19.14^{\mathrm{Aa}}$ & $10.13^{\mathrm{Be}}$ & $4.43^{\mathrm{Ci}}$ & 30 & $11.54^{\mathrm{Ac}}$ & $5.87^{\mathrm{Bd}}$ & $4.32^{\mathrm{Cf}}$ \\
\hline 6 & - & $17.7^{\mathrm{Ac}}$ & $10.31^{\mathrm{Bf}}$ & 30 & - & $13.21^{\mathrm{Ad}}$ & $6.21^{\mathrm{Bh}}$ & 60 & $17.87^{\mathrm{Ab}}$ & $9.72^{\mathrm{Bc}}$ & $7.88^{\mathrm{Ce}}$ \\
\hline 9 & - & $19.93^{\mathrm{Ab}}$ & $15.11^{\mathrm{Be}}$ & 45 & - & $16.17^{\mathrm{Ac}}$ & $8.84^{\mathrm{Bg}}$ & 90 & $21.57^{\mathrm{Aa}}$ & $15.47^{\mathrm{Bb}}$ & $12.40^{\mathrm{Cd}}$ \\
\hline 12 & - & $21.15^{\mathrm{Aa}}$ & $16.91^{\mathrm{Bd}}$ & 60 & - & $18.43^{\mathrm{Ab}}$ & $11.63^{\mathrm{Bf}}$ & 120 & - & $19.95^{\mathrm{Aa}}$ & $16.52^{\mathrm{Bc}}$ \\
\hline 15 & - & - & $17.83^{\mathrm{c}}$ & 75 & - & $22.18^{\mathrm{Aa}}$ & $13.42^{\mathrm{Be}}$ & 150 & - & - & $18.32^{\mathrm{b}}$ \\
\hline 18 & - & - & $19.81^{b}$ & 90 & - & - & $15.47^{\mathrm{d}}$ & 180 & - & - & $21.10^{\mathrm{a}}$ \\
\hline- & - & - & & 105 & - & - & $17.95^{\mathrm{c}}$ & - & - & - & - \\
\hline- & - & - & - & 120 & - & - & $18.57^{b}$ & - & - & - & - \\
\hline - & - & - & - & 135 & - & - & $19.42^{\mathrm{a}}$ & - & - & - & - \\
\hline
\end{tabular}

Mean values in the same row (as a capital letter) or column (as a small letter) with the same letter are not significantly different $(\mathrm{P}>0.05)$. A.P: aerobic packaged V.P: vacuum packaged.

Table 2. Effect of some hurdles technology on TBA $(\mathrm{mg} / \mathrm{kg})$ of chicken fillet samples storage at different conditions:

\begin{tabular}{|c|c|c|c|c|c|c|c|c|c|c|c|}
\hline \multicolumn{4}{|c|}{ Storage at room temperature $\left(25 \pm 5 \mathrm{C}^{\circ}\right)$} & \multicolumn{4}{|c|}{ Storage at cold temperature $\left(4 \pm 2 \mathrm{C}^{\circ}\right)$} & \multicolumn{4}{|c|}{ Storage at frozen temperature $\left(-18 \pm 2 C^{\circ}\right)$} \\
\hline Treatment & & & & Treatment & & & & Treatment & & & \\
\hline $\begin{array}{c}\text { Storage } \\
\text { (day) }\end{array}$ & Control & A.P & V.P & $\begin{array}{c}\text { Storage } \\
\text { (day) }\end{array}$ & Control & A.P & V.P & $\begin{array}{c}\text { Storage } \\
\text { (day) }\end{array}$ & Control & A.P & V.P \\
\hline $\mathbf{0}$ & $0.183^{\mathrm{Bb}}$ & $0.189^{\mathrm{Be}}$ & $0.198^{\mathrm{Ag}}$ & $\mathbf{0}$ & $0.183^{\mathrm{Ab}}$ & $0.160^{\mathrm{Bf}}$ & $0.187^{\mathrm{Aj}}$ & $\mathbf{0}$ & $0.183^{\mathrm{Ad}}$ & $\begin{array}{c}0.178^{\mathrm{A}} \\
\mathrm{e}\end{array}$ & $\begin{array}{c}0.165^{\mathrm{B}} \\
\mathrm{g}\end{array}$ \\
\hline 3 & $0.901^{\mathrm{Aa}}$ & $0.331^{\mathrm{Bd}}$ & $0.281^{\mathrm{Cf}}$ & 15 & $0.956^{\mathrm{Aa}}$ & $0.291^{\mathrm{Be}}$ & $0.275^{\mathrm{Ci}}$ & 30 & $0.654^{\mathrm{Ac}}$ & $\begin{array}{c}0.578^{B} \\
d\end{array}$ & $0.352^{\mathrm{Cf}}$ \\
\hline 6 & - & $0.741^{\mathrm{Ac}}$ & $0.401^{\mathrm{Be}}$ & 30 & - & $0.581^{\mathrm{Ad}}$ & $\begin{array}{c}0.396^{\mathrm{B}} \\
\mathrm{h}\end{array}$ & 60 & $0.895^{\mathrm{Ab}}$ & $0.759^{\mathrm{Bc}}$ & $0.564^{\mathrm{Ce}}$ \\
\hline 9 & - & $0.853^{\mathrm{Ab}}$ & $0.632^{\mathrm{Bd}}$ & 45 & - & $0.747^{\mathrm{Ac}}$ & $\begin{array}{c}0.470^{B} \\
g\end{array}$ & 90 & $1.250^{\mathrm{Aa}}$ & $\begin{array}{c}0.802^{\mathrm{B}} \\
\mathrm{b}\end{array}$ & $\begin{array}{c}0.674^{\mathrm{C}} \\
\mathrm{d}\end{array}$ \\
\hline 12 & - & $0.998^{\text {Аа }}$ & $0.863^{\mathrm{Bc}}$ & 60 & - & $0.831^{\mathrm{Ab}}$ & $0.598^{\mathrm{Bf}}$ & 120 & - & $\begin{array}{c}0.901^{\mathrm{A}} \\
\mathrm{a}\end{array}$ & $0.781^{\mathrm{Bc}}$ \\
\hline 15 & - & - & $0.892^{\mathrm{b}}$ & 75 & - & $0.879^{\text {Aa }}$ & $0.617^{\mathrm{Be}}$ & 150 & - & - & $0.874^{\mathrm{b}}$ \\
\hline- & - & - & - & 105 & - & - & $0.775 \mathrm{c}$ & - & - & - & - \\
\hline- & - & - & - & 120 & - & - & $0.826^{\mathrm{b}}$ & - & - & - & - \\
\hline- & - & - & - & 135 & - & - & $0.870^{\mathrm{a}}$ & - & - & - & - \\
\hline
\end{tabular}

Mean values in the same row (as a capital letter) or column (as a small letter) with the same letter are not significantly different $(\mathrm{P}>0.05)$. A.P: aerobic packaged V.P: vacuum packaged

Table 3. Effect some hurdles technology on $\mathrm{pH}$ value of chicken fillet samples storage at different conditions:

\begin{tabular}{|c|c|c|c|c|c|c|c|c|c|c|c|}
\hline \multicolumn{4}{|c|}{ Storage at room temperature $\left(25 \pm 5 \mathrm{C}^{\circ}\right)$} & \multicolumn{4}{|c|}{ Storage at cold temperature $\left(4 \pm 2 \mathrm{C}^{\circ}\right)$} & \multicolumn{4}{|c|}{ Storage at frozen temperature $\left(-18 \pm 2 \mathrm{C}^{\circ}\right)$} \\
\hline Treatment & & & & Treatment & & & & Treatment & & & \\
\hline $\begin{array}{c}\text { Storage } \\
\text { (day) }\end{array}$ & Control & A.P & V.P & $\begin{array}{c}\text { Storage } \\
\text { (day) }\end{array}$ & Control & A.P & V.P & $\begin{array}{c}\text { Storage } \\
\text { (day) }\end{array}$ & Control & A.P & V.P \\
\hline $\mathbf{0}$ & $5.64^{\mathrm{Ab}}$ & $4.51^{\mathrm{Be}}$ & $4.49^{\mathrm{Bg}}$ & $\mathbf{0}$ & $5.64^{\mathrm{Ab}}$ & $4.51^{\mathrm{Bf}}$ & $4.52^{\mathrm{Bj}}$ & $\mathbf{0}$ & $5.64^{\mathrm{Ad}}$ & $4.50^{\mathrm{Be}}$ & $4.52^{\mathrm{Bg}}$ \\
\hline 3 & 7.04 $\mathrm{Aa}$ & $4.98^{\mathrm{Bd}}$ & $4.97^{\mathrm{Bf}}$ & 15 & $6.86^{\mathrm{Aa}}$ & $4.71^{\mathrm{Be}}$ & $4.62^{\mathrm{Bi}}$ & 30 & $6.15^{\mathrm{Ac}}$ & $4.82^{\mathrm{Bd}}$ & $4.79^{\mathrm{Bf}}$ \\
\hline 6 & - & $5.68^{\mathrm{Ac}}$ & $5.47^{\mathrm{Be}}$ & 30 & - & $5.47^{\mathrm{Ad}}$ & $5.11^{\mathrm{Bh}}$ & 60 & $6.72^{\mathrm{Ab}}$ & $5.43^{\mathrm{Bc}}$ & $5.36^{\mathrm{Ce}}$ \\
\hline 9 & - & $6.43^{\mathrm{Ab}}$ & $6.31^{\mathrm{Bd}}$ & 45 & - & $6.20^{\mathrm{Ac}}$ & $5.42^{\mathrm{Bg}}$ & 90 & $7.11^{\mathrm{Aa}}$ & $5.93^{\mathrm{Bb}}$ & $5.68^{\mathrm{Cd}}$ \\
\hline 12 & - & $7.12^{\mathrm{Aa}}$ & $6.87^{\mathrm{Bc}}$ & 60 & - & $7.02^{\mathrm{Ab}}$ & $5.87^{\mathrm{Bf}}$ & 120 & - & $6.75^{\mathrm{Aa}}$ & $6.47^{\mathrm{Bc}}$ \\
\hline 15 & - & - & $7.13^{\mathrm{b}}$ & 75 & - & $7.40^{\mathrm{Aa}}$ & $6.13^{\mathrm{Be}}$ & 150 & - & - & $6.83^{b}$ \\
\hline 18 & - & - & $7.34^{\mathrm{a}}$ & 90 & - & - & $6.51^{\mathrm{d}}$ & 180 & - & - & $7.10^{\mathrm{a}}$ \\
\hline- & - & - & - & 105 & - & - & $6.74^{\mathrm{c}}$ & - & - & - & - \\
\hline- & - & - & - & 120 & - & - & $6.90^{\mathrm{b}}$ & - & - & - & - \\
\hline- & - & - & - & 135 & - & - & $7.09^{\mathrm{a}}$ & - & - & - & - \\
\hline
\end{tabular}

Mean values in the same row (as a capital letter) or column (as a small letter) with the same letter are not significantly different $(\mathrm{P}>0.05)$. A.P: aerobic packaged V.P: vacuum packaged 
Table 4. Effect of some hurdles technology on frying loss (\%) of chicken fillet samples storage at different conditions:

\begin{tabular}{|c|c|c|c|c|c|c|c|c|c|c|c|}
\hline \multicolumn{4}{|c|}{ Storage at room temperature $\left(25 \pm 5 \mathrm{C}^{\circ}\right)$} & \multicolumn{4}{|c|}{ Storage at cold temperature $\left(4 \pm 2 \mathrm{C}^{\circ}\right)$} & \multicolumn{4}{|c|}{ Storage at frozen temperature $\left(-18 \pm 2 \mathrm{C}^{\circ}\right)$} \\
\hline Treatment & & & & Treatment & & & & Treatment & & & \\
\hline $\begin{array}{c}\text { Storage } \\
\text { (day) }\end{array}$ & Control & A.P & V.P & $\begin{array}{c}\text { Storage } \\
\text { (day) }\end{array}$ & Control & A.P & V.P & $\begin{array}{c}\text { Storage } \\
\text { (day) }\end{array}$ & Control & A.P & V.P \\
\hline $\mathbf{0}$ & $12.78^{\mathrm{Ab}}$ & $12.77^{\mathrm{Ae}}$ & $12.80^{\mathrm{Ah}}$ & $\mathbf{0}$ & $12.78^{\mathrm{Ab}}$ & $12.80^{\mathrm{Af}}$ & $12.81^{\mathrm{Aj}}$ & $\mathbf{0}$ & $12.78^{\mathrm{Ad}}$ & $12.80^{\mathrm{Ae}}$ & $12.79^{\mathrm{Ag}}$ \\
\hline 3 & $13.64^{\mathrm{Aa}}$ & $12.96^{\mathrm{Bd}}$ & $12.94^{\mathrm{Bg}}$ & 15 & $13.47^{\mathrm{Aba}}$ & $12.96^{\mathrm{Be}}$ & $12.93^{\mathrm{Bi}}$ & 30 & $12.97^{\mathrm{Ac}}$ & $12.96^{\mathrm{Ad}}$ & $12.90^{\mathrm{Bf}}$ \\
\hline 6 & - & $13.13^{\mathrm{Ac}}$ & $13.08^{\mathrm{Bf}}$ & 30 & - & $13.13^{\mathrm{Ad}}$ & $13.09^{\mathrm{Ah}}$ & 60 & $13.21^{\mathrm{Ab}}$ & $13.18^{\mathrm{Bc}}$ & $13.02^{\mathrm{Ce}}$ \\
\hline 9 & - & $13.34^{\mathrm{Ab}}$ & $13.22^{\mathrm{Be}}$ & 45 & - & $13.29^{\mathrm{Ac}}$ & $13.20^{\mathrm{Bg}}$ & 90 & $13.40^{\mathrm{Aa}}$ & $13.35^{\mathrm{Bb}}$ & $13.18^{\mathrm{Cd}}$ \\
\hline 12 & - & $13.68^{\mathrm{Aa}}$ & $13.43^{\mathrm{Bd}}$ & 60 & - & $13.42^{\mathrm{Ab}}$ & $13.38^{\mathrm{Bf}}$ & 120 & - & $13.49^{\mathrm{Aa}}$ & $13.35^{\mathrm{Bc}}$ \\
\hline 15 & - & - & $13.67^{\mathrm{c}}$ & 75 & - & $13.63^{\mathrm{Aa}}$ & $13.57^{\mathrm{Be}}$ & 150 & - & - & $13.44^{\mathrm{b}}$ \\
\hline 18 & - & - & $13.77^{\mathrm{b}}$ & 90 & - & - & $13.70^{\mathrm{d}}$ & 180 & - & - & $13.56^{\mathrm{a}}$ \\
\hline - & - & - & - & 105 & - & - & $13.85^{\mathrm{c}}$ & - & - & - & - \\
\hline - & - & - & - & 120 & - & - & $13.97^{b}$ & - & - & - & - \\
\hline - & - & - & - & 135 & - & - & $14.09^{\mathrm{a}}$ & - & - & - & - \\
\hline
\end{tabular}

Mean values in the same row (as a capital letter) or column (as a small letter) with the same letter are not significantly different $(\mathrm{P}>0.05)$. A.P: aerobic packaged V.P: vacuum packaged

Table 5. Effect of some hurdles technology on color $(\Delta \mathrm{E})$ of chicken fillet samples storage at different conditions:

\begin{tabular}{|c|c|c|c|c|c|c|c|c|c|c|c|}
\hline \multicolumn{8}{|c|}{ Storage at room temperature $\left(25 \pm 5 \mathrm{C}^{\circ}\right)$ Storage at cold temperature $\left(4 \pm 2 \mathrm{C}^{\circ}\right)$} & \multicolumn{4}{|c|}{ Storage at frozen temperature $\left(-18 \pm 2 \mathrm{C}^{\circ}\right)$} \\
\hline Treatment & & & & Treatmen & & & & Treatment & & & \\
\hline $\begin{array}{c}\text { Storage } \\
\text { (day) }\end{array}$ & Control & A.P & V.P & $\begin{array}{c}\text { Storage } \\
\text { (day) }\end{array}$ & Control & A.P & V.P & $\begin{array}{c}\text { Storage } \\
\text { (day) }\end{array}$ & Control & A.P & V.P \\
\hline $\mathbf{0}$ & $38.10^{\mathrm{Ab}}$ & $38.19^{\mathrm{Ad}}$ & $37.82^{\mathrm{Bg}}$ & $\mathbf{0}$ & $38.10^{\mathrm{Ab}}$ & $38.08^{\mathrm{Ae}}$ & $38.08^{\mathrm{Aj}}$ & $\mathbf{0}$ & $38.10^{\mathrm{Ad}}$ & $38.03^{\mathrm{Ae}}$ & $37.99^{\mathrm{Ag}}$ \\
\hline 3 & $40.92^{\mathrm{Aa}}$ & $39.68^{\mathrm{Bc}}$ & $39.55^{\mathrm{Cf}}$ & 15 & $40.87^{\mathrm{Aa}}$ & $39.55^{\mathrm{Bd}}$ & $39.55^{\mathrm{Bi}}$ & 30 & $40.40^{\mathrm{Ac}}$ & $40.02^{\mathrm{Bd}}$ & $39.84^{\mathrm{Cf}}$ \\
\hline 6 & - & $40.78^{\mathrm{Bb}}$ & $40.60^{\mathrm{Be}}$ & 30 & - & $40.76^{\mathrm{Bc}}$ & $40.82^{\mathrm{Ah}}$ & 60 & $40.82^{\mathrm{Ab}}$ & $40.50^{\mathrm{Bc}}$ & $40.14^{\mathrm{Ce}}$ \\
\hline 9 & - & $40.88^{\mathrm{Ba}}$ & $40.78^{\mathrm{Bd}}$ & 45 & - & $41.12^{\mathrm{Ab}}$ & $40.95^{\mathrm{Bg}}$ & 90 & $41.13^{\mathrm{Aa}}$ & $40.79^{\mathrm{Bb}}$ & $40.49^{\mathrm{Cd}}$ \\
\hline 12 & - & $40.92^{\mathrm{Ba}}$ & $40.85^{\mathrm{Ac}}$ & 60 & - & $41.42^{\mathrm{Aa}}$ & $41.13^{\mathrm{Bf}}$ & 120 & - & $41.02^{\mathrm{Aa}}$ & $40.76^{\mathrm{Bc}}$ \\
\hline 15 & - & - & $41.08^{\mathrm{b}}$ & 75 & - & - & $41.30^{\mathrm{e}}$ & 150 & - & - & $41.00^{\mathrm{b}}$ \\
\hline 18 & - & - & $41.21^{\mathrm{a}}$ & 90 & - & - & $41.44^{\mathrm{d}}$ & 180 & - & - & $41.16^{\mathrm{a}}$ \\
\hline - & - & - & - & 105 & - & - & $41.57^{\mathrm{c}}$ & - & - & - & - \\
\hline - & - & - & - & 120 & - & - & $41.71^{\mathrm{b}}$ & - & - & - & - \\
\hline- & - & - & - & 135 & - & - & $41.85^{\mathrm{a}}$ & - & - & - & - \\
\hline
\end{tabular}

Mean values in the same row (as a capital letter) or column (as a small letter) with the same letter are not significantly different $(\mathrm{P}>0.05)$. A.P: aerobic packaged V.P: vacuum packaged

Table 6. Effect of some hurdles technology on total bacterial count (log cfu/g) of chicken fillet samples storage at different conditions:

\begin{tabular}{|c|c|c|c|c|c|c|c|c|c|c|c|}
\hline \multirow{2}{*}{$\frac{\text { Storage at }}{\text { Treatment }}$} & om tempe & ture ( & $\left.5 \mathrm{C}^{\circ}\right)$ & \multicolumn{4}{|c|}{ Storage at cold temperature $\left(4 \pm 2 \mathrm{C}^{\circ}\right)$} & \multicolumn{4}{|c|}{ Storage at frozen temperature $\left(-18 \pm 2 C^{\circ}\right)$} \\
\hline & & & & Treatment & & & & Treatment & & & \\
\hline $\begin{array}{c}\text { Storage } \\
\text { (day) }\end{array}$ & Control & A.P & V.P & $\begin{array}{c}\text { Storage } \\
\text { (day) }\end{array}$ & Control & A.P & V.P & $\begin{array}{c}\text { Storage } \\
\text { (day) }\end{array}$ & Control & A.P & V.P \\
\hline $\mathbf{0}$ & 1.83 & 1.77 & 1.76 & $\mathbf{0}$ & 1.83 & 1.73 & 1.67 & $\mathbf{0}$ & 1.83 & 1.65 . & 1.63 \\
\hline 3 & 4.10 & 2.15 & 2.00 & 15 & 4.14 & 2.11 & 1.93 & 30 & 2.87 & 2.10 & 1.98 \\
\hline 6 & - & 2.83 & 2.43 & 30 & - & 2.74 & 2.10 & 60 & 3.68 & 2.98 & 2.45 \\
\hline 9 & - & 3.41 & 3.04 & 45 & - & 3.21 & 2.89 & 90 & 4.33 & 3.42 & 3.01 \\
\hline 12 & - & 4.13 & 3.48 & 60 & - & 3.68 & 3.02 & 120 & - & 4.12 & 3.47 \\
\hline 15 & - & - & 3.99 & 75 & - & 3.98 & 3.11 & 150 & - & - & 3.85 \\
\hline 18 & - & - & 4.47 & 90 & - & - & 3.21 & 180 & - & - & 4.11 \\
\hline- & - & - & - & 105 & - & - & 3.32 & - & - & - & - \\
\hline- & - & - & - & 120 & - & - & 3.41 & - & - & - & - \\
\hline- & - & - & - & 135 & - & - & 3.59 & - & - & - & - \\
\hline
\end{tabular}

A.P: aerobic packaged V.P: vacuum packaged 
Table 7. Effect of some hurdles technology on psychrophilic bacteria count (log cfu/g) of chicken fillet samples storage at different conditions:

\begin{tabular}{|c|c|c|c|c|c|c|c|}
\hline \multicolumn{4}{|c|}{ Storage at cold temperature $\left(4 \pm 2 \mathrm{C}^{\circ}\right)$} & \multicolumn{4}{|c|}{ Storage at frozen temperature $\left(-18 \pm 2 C^{\circ}\right)$} \\
\hline Treatment & & & & Treatment & & & \\
\hline $\begin{array}{c}\text { Storage } \\
\text { (day) }\end{array}$ & Control & A.P & V.P & $\begin{array}{c}\text { Storage } \\
\text { (day) }\end{array}$ & Control & A.P & V.P \\
\hline $\mathbf{0}$ & 1.10 & 1.08 & 1.08 & $\mathbf{0}$ & 1.10 & 1.07 & 1.08 \\
\hline 15 & 2.16 & 1.28 & 1.20 & 30 & 1.48 & 1.30 & 1.21 \\
\hline 30 & - & 1.43 & 1.32 & 60 & 1.87 & 1.57 & 1.42 \\
\hline 45 & - & 1.65 & 1.54 & 90 & 2.20 & 1.74 & 1.63 \\
\hline 60 & - & 1.79 & 1.63 & 120 & - & 1.89 & 1.77 \\
\hline 75 & - & 1.88 & 1.71 & 150 & - & - & 1.85 \\
\hline 90 & - & - & 1.84 & 180 & - & - & 1.93 \\
\hline 105 & - & - & 2.00 & - & - & - & - \\
\hline 120 & - & - & 2.13 & - & - & - & - \\
\hline 135 & - & - & 2.24 & - & - & - & - \\
\hline
\end{tabular}

A.P: aerobic packaged V.P: vacuum packaged

Table 8. Effect some of hurdles technology on coliform group (log cfu/g) of chicken fillet samples storage at different conditions:

\begin{tabular}{|c|c|c|c|c|c|c|c|c|c|c|c|}
\hline \multicolumn{4}{|c|}{ Storage at room temperature $\left(25 \pm 5 \mathrm{C}^{\circ}\right)$} & \multicolumn{4}{|c|}{ Storage at cold temperature $\left(4 \pm 2 \mathrm{C}^{\circ}\right)$} & \multicolumn{4}{|c|}{ Storage at frozen temperature $\left(-18 \pm 2 \mathrm{C}^{\circ}\right)$} \\
\hline Treatment & & & & Treatment & & & & Treatment & & & \\
\hline $\begin{array}{c}\text { Storage } \\
\text { (day) }\end{array}$ & Control & A.P & V.P & $\begin{array}{c}\text { Storage } \\
\text { (day) }\end{array}$ & Control & A.P & V.P & $\begin{array}{c}\text { Storage } \\
\text { (day) }\end{array}$ & Control & A.P & V.P \\
\hline $\mathbf{0}$ & 1.21 & 1.20 & 1.19 & $\mathbf{0}$ & 1.21 & 1.18 & 1.18 & $\mathbf{0}$ & 1.21 & 1.19 & 1.18 \\
\hline 3 & 2.57 & 1.41 & 1.28 & 15 & 2.07 & 1.29 & 1.24 & 30 & 1.49 & 1.39 & 1.28 \\
\hline 6 & - & 1.68 & 1.40 & 30 & - & 1.43 & 1.38 & 60 & 1.73 & 1.58 & 1.42 \\
\hline 9 & - & 1.89 & 1.58 & 45 & - & 1.68 & 1.42 & 90 & 1.98 & 1.77 & 1.53 \\
\hline 12 & - & 2.09 & 1.72 & 60 & - & 1.81 & 1.63 & 120 & - & 1.92 & 1.69 \\
\hline 15 & - & - & 1.89 & 75 & - & 1.97 & 1.70 & 150 & - & - & 1.78 \\
\hline 18 & - & - & 2.10 & 90 & - & - & 1.81 & 180 & - & - & 1.87 \\
\hline - & - & - & - & 105 & - & - & 1.92 & - & - & - & - \\
\hline- & - & - & - & 120 & - & - & 2.00 & - & - & - & - \\
\hline- & - & - & - & 135 & - & - & 2.09 & - & - & - & - \\
\hline
\end{tabular}

A.P: aerobic packaged V.P: vacuum packaged

Table 9. Effect of some hurdles technology on mold and yeast counts (log cfu/g) of chicken fillet samples storage at different conditions:

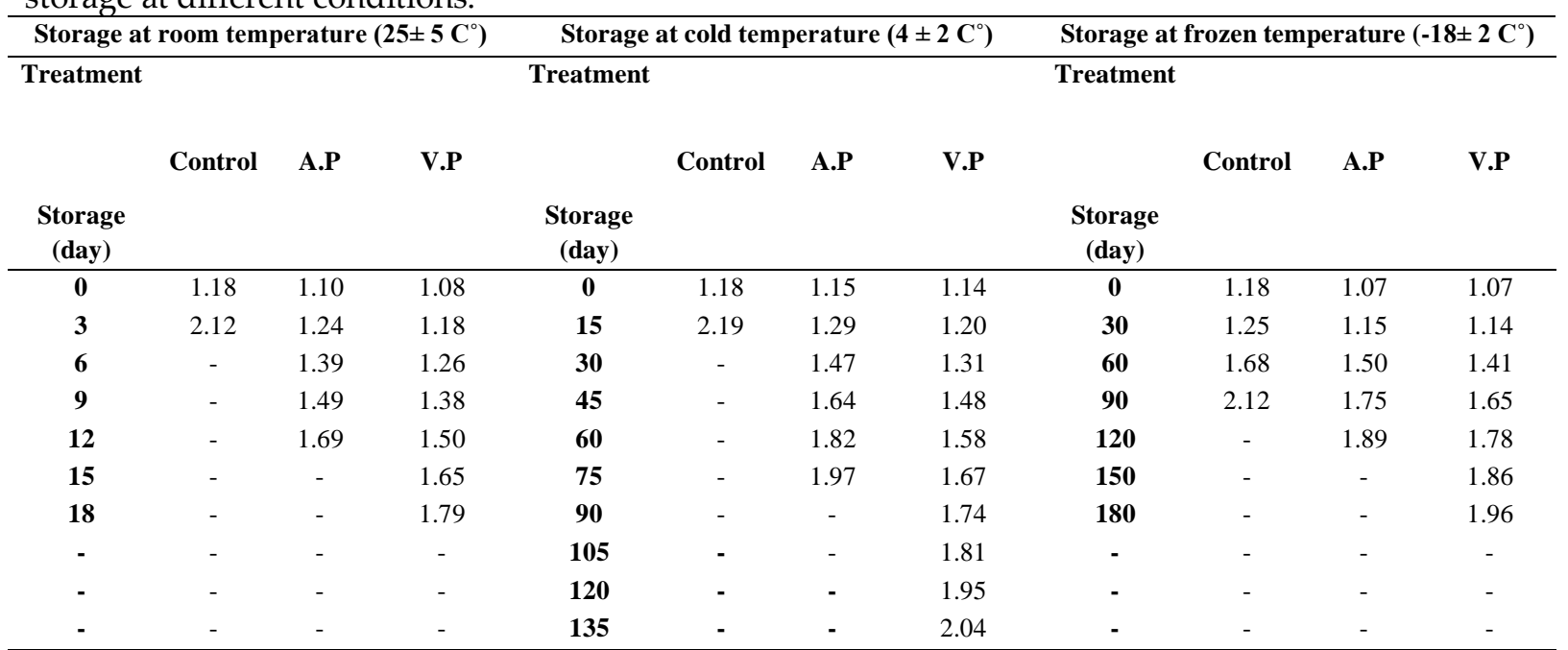

A.P: aerobic packaged V.P: vacuum packaged 
Table 10. Effect of some hurdles technology on anaerobic bacteria count (log cfu/g) of chicken fillet samples storage at different conditions:

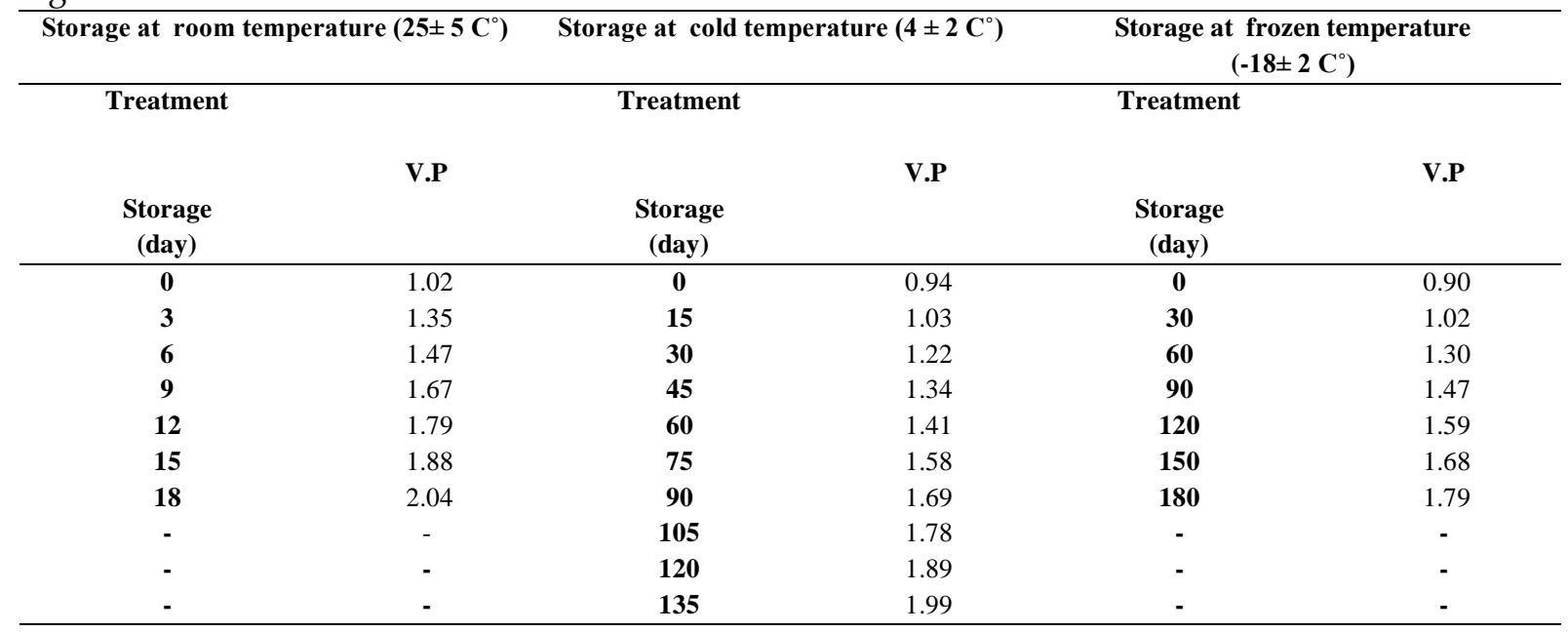

V.P: vacuum packaged. 
Table 11. Mean values of sensory characteristics of chicken fillet samples as affected by some hurdles technology during storage at different conditions:

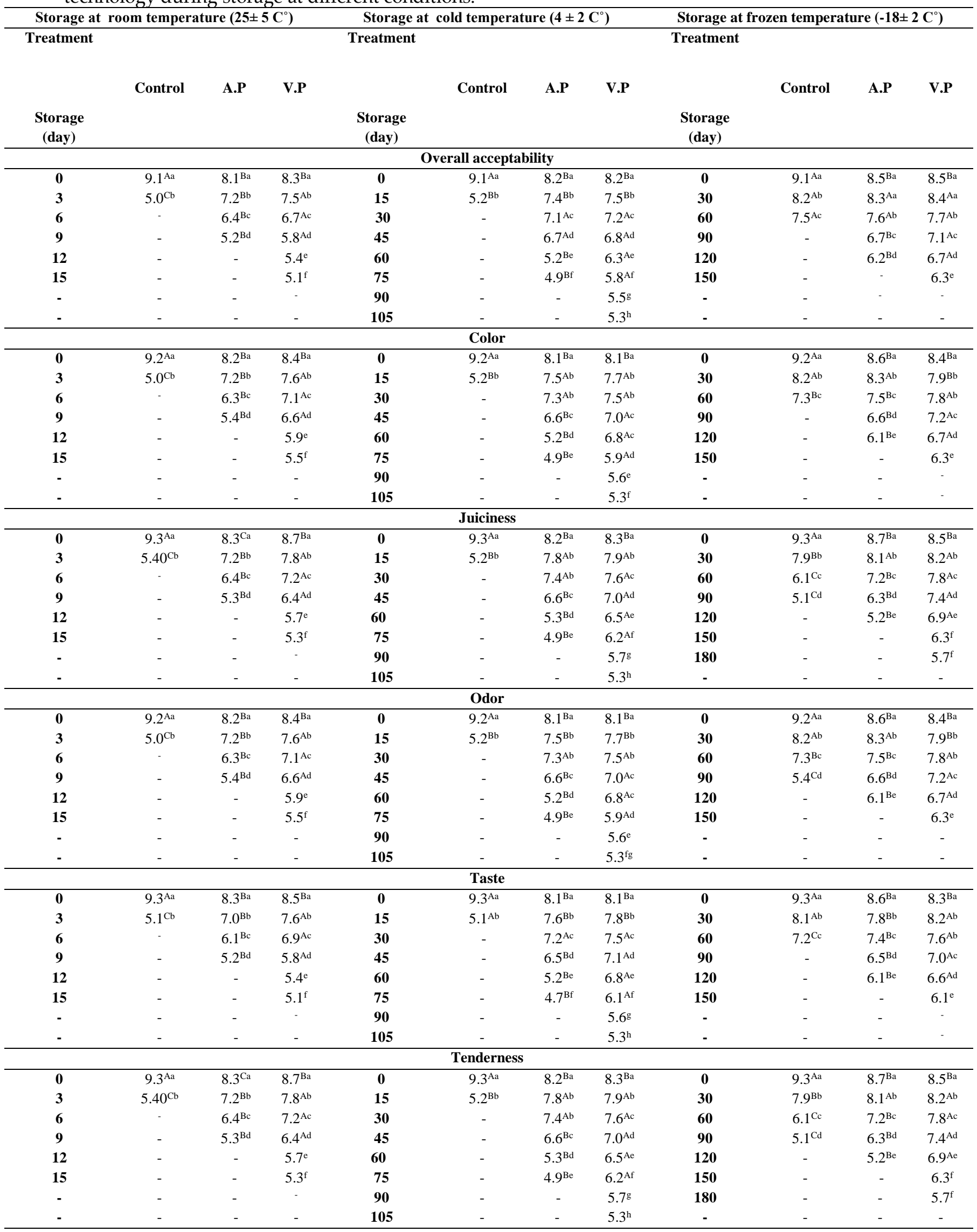




\section{استخدام تثنية الحفظ المتداخل لتحسين خصائص الجودة لفيليه الدجاج أثناء التخزين \\ محمد إيراهيم محمد إيراهيم 1"، أحمد إبراهيم محمد جازى 1، عاطف سعد عبد المنعم عشيبة 2، أشرف مرسى محمد نجيب 1

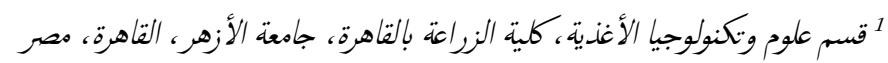

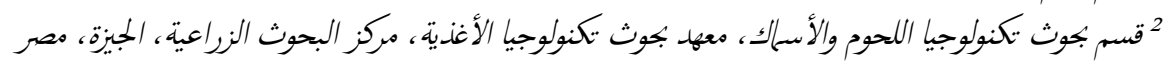

|البريد الإيكتروني للباحث الرئيس: Mohammedibrahim700.el@azhar.edu.eg

الملخص العربى

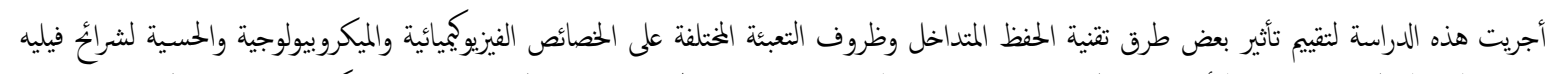

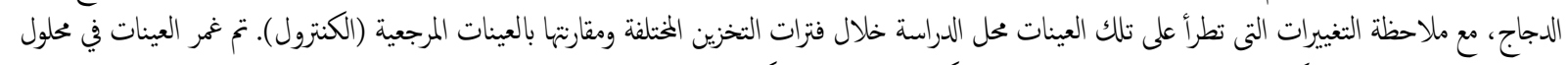

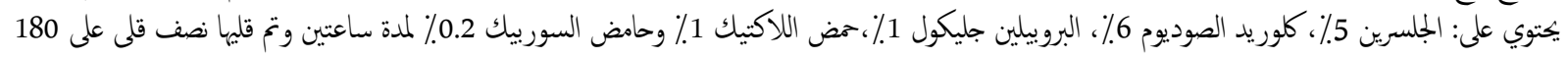

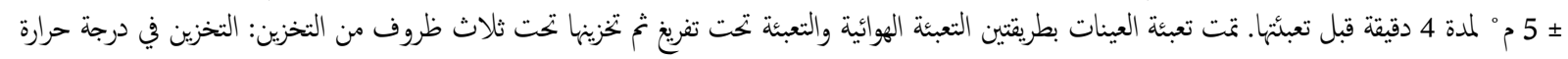

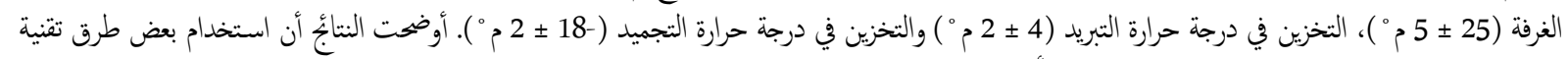

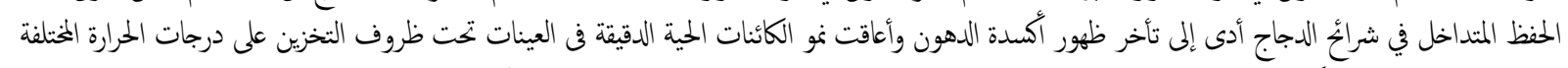

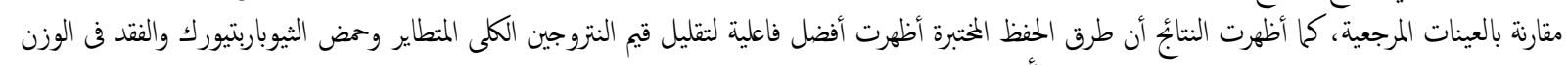

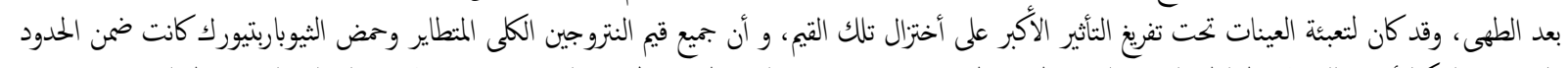

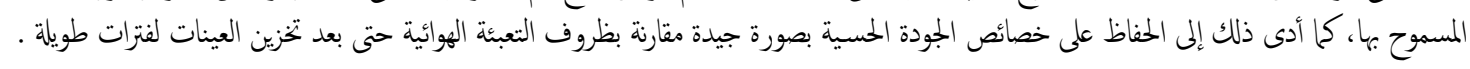

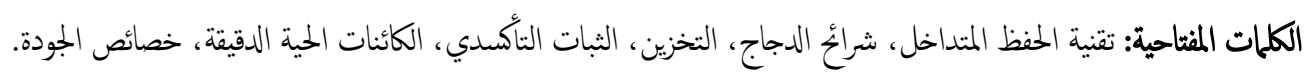

